\title{
Interrupting the Politics of Learning
}

\author{
GERT BIESTA \\ Faculty of Language and Literature, Humanities, Arts and Education, \\ University of Luxembourg
}

\begin{abstract}
In this article, the author raises critical questions about the notion of 'learning', the language of 'learning' and the discourse of 'learning'. The analytical and critical device used is the idea of the 'politics of learning', through which the author highlights the powerful work that is being done by, and which at the very same time is hidden behind, the discourse of 'learning'. The author focuses on the field of lifelong learning, not only because it is here that claims about and demands for learning are most explicitly articulated, but also because this field, through both policy and research, is contributing most strongly to an apparent 'common sense' about learning in contemporary societies. Based on this analysis, the author argues that there is a need for an interruption of the politics of learning in order to reclaim the emancipatory potential of education.
\end{abstract}

To live, by definition, is not something one learns. (Derrida, 1994, p. xviii)

\section{Introduction: learning, learning, learning}

In the preamble to his book Spectres of Marx, Jacques Derrida (1994, p. xviii ) writes that: 'To live, by definition, is not something one learns'. If this is indeed so, and if it is so by definition, then the following lines, taken from the preface of UNESCO's report from the 2010 Shanghai International Forum on Lifelong Learning, may perhaps sound a little 'out of joint'. They read:

We are now living in a fast-changing and complex social, economic and political world to which we need to adapt by increasingly rapidly acquiring new knowledge, skills and attitudes in a wide range of contexts. An individual will not be able to meet life challenges unless he or she becomes a lifelong learner, and a society will not be sustainable unless it becomes a learning society.

(Yang \& Valdés-Cotera, 2011, p. v)

Claims like these - which almost sound like threats (You will not be able to meet life challenges unless you become a lifelong learner! Society will not be sustainable unless it becomes a learning society!) - have become all too familiar in recent times, so that it may well be argued that we now live in a 'learning age' (which, incidentally, was the title of a United Kingdom government consultation paper from 1998 that even promised 'a renaissance for a new Britain' - see Department for Education and Employment, 1998).

In the learning age, we are surrounded by claims that learning is something good and desirable, and often by claims that it is intrinsically good and desirable. We are also surrounded by claims that learning is something inevitable, something we have to do and cannot not do, and therefore something that should not only take place in schools, colleges and universities, but actually should go on throughout our lives, both extended in time (the idea of lifelong learning) and extended in space (the idea of life-wide learning - that is, learning which permeates all aspects of our lives). But is learning indeed 'the treasure within', as was suggested in the title of the 1996 UNESCO report (Delors et al, 1996) written by Jacques Delors and colleagues? Is learning indeed inevitable? Is it indeed an 'unavoidable biological fact [that] we learn as we breathe, all the time, 
without giving it any thought' (Field, 2000, p. 35)? Is learning therefore indeed something that should permeate our lives, from dusk to dawn, from cradle to grave, from womb to tomb? And is it therefore entirely reasonable to have European Lifelong Learning Indicators that measure in extreme detail how 'well' each and every European country, and within each country ultimately every individual, is doing in its learning (see ELLI Development Team, 2008; see also Biesta, 2012a)?

In this article, I would like to raise a number of critical questions about the 'learning age' that is, about the apparent omnipresence of learning in our times and our lives. These questions partly have to do with discourse - that is, with the discourse of learning and its problems. They partly have to do with power - that is, with the ways in which through the discourse of learning power is being exercised. And they have to do with resistance - that is, with the question of whether we should resist the 'demand' for learning and, if so, how we might be able to do this.

I come to these questions as an educator and educationalist, as I think that the language of learning has been utterly unhelpful in the double educational task of engagement with and emancipation from the world - both the material and the social world (on this formulation of the task of education, see, for example, Meirieu, 2007). The analytical and critical device I will use in my article is the idea of the 'politics of learning', through which I will highlight the powerful work that is being done by, and at the very same time is hidden behind, the discourse of 'learning'. The field of discussion is that of lifelong learning, not only because it is here that claims about and demands for learning are most explicitly articulated, but also because this field, through both policy and research, is contributing most strongly to an apparent common sense about learning in contemporary societies.

I will develop my ideas in five steps. I will start with the discourse of learning, indicating, on the one hand, the ongoing 'learnification' of the discourse of education and highlighting, on the other hand, some problems with the very idea of 'learning'. Against this background, I then look at shifts in the 'field' of lifelong learning (and here we should note that to name this 'field' in terms of learning is already part of the problem I wish to address) in order to explore some aspects of a politics of learning that is working through it. I will then make some suggestions for how we might resist the tendency to naturalise learning - that is, to put it on an equal footing with breathing and digestion - both at the level of theory and the level of practice. From there I turn to the question of emancipation in order to explore how we might think of and 'do' emancipation outside of the confines of a politics of learning. What such an emancipation without learning might look like is something which, in the fifth step, I illustrate through the work of Foucault. After this, I will make some concluding remarks to draw the lines of my argument together.

\section{The Problem with 'Learning'}

Over the past two decades, the word 'learning' has become a popular concept in educational research, policy and practice. Elsewhere (Biesta, 2010a), I have characterised the rapid increase in the use of the word 'learning' and the rise of a wider 'language of learning' as the learnification of educational discourse and practice. This process is visible in a number of discursive shifts, such as the tendency to refer to education as 'teaching and learning'; to refer to students as 'learners' and to adults as 'adult learners'; to see teachers as 'facilitators of learning'; and to conceive of schools as 'learning environments' or 'places for learning' - the latter being the phrase used to designate Watercliffe Meadow, a primary school in Sheffield, allegedly because the word 'school' had such a negative connotation with pupils and parents.[1] The shift from 'adult education' to 'lifelong learning' is another prominent manifestation of the rise of this 'new language of learning' (Biesta, 2006a).

The rise of the 'new language of learning' is the result - and perhaps we should say partly unintended outcome - of a number of developments. These include: (1) the impact of new theories of learning, particularly constructivist theories, which put the focus more strongly on students and their activities than on teachers and their input; (2) the (postmodern) critique of authoritarian forms of teaching; (3) what John Field (2000) has called the 'silent explosion' of learning - that is, the fact that more and more people are engaged in more and more different forms and modes of learning, particularly non-formal and informal ones; and (4) the individualising impact of neo- 
liberal policies and politics on education, including adult education (a point to which I will return below). The rise of the language of learning has, in some cases, empowered those at the receiving end of the spectrum, particularly where teaching was conceived in narrow, controlling and authoritarian ways. But the rise of a language of learning has also had some less desirable consequences. These have to do with two aspects of the concept of 'learning', one being that 'learning' is a process term and the other that 'learning', unlike 'education', is an individualistic and individualising term.

To begin with the first point: in the English language, 'learning' generally denotes a process or an activity. This means, however, that the word 'learning' is in itself neutral or empty with regard to content, direction and purpose. To suggest that learning is good or desirable - and thus to suggest that it is something which should go on throughout one's life or which should be promoted in schools - does therefore not really mean anything until it is specified what the content of the learning is and, more importantly, until it is specified what the purpose of the learning is. The emptiness of the notion of 'learning' has made its rise in educational settings quite problematic, as the point of education - be it school education or the education of adults - is never just that students learn, but that they learn something and that they learn this for particular reasons. The language of learning has made it far more difficult to engage with the question of purpose, to the extent that in many instances this question has virtually disappeared from the discussion (see Biesta, 2010a). The fact that 'learning' is an individualistic and individualising term - learning is, after all, something one can only do for oneself; it is not possible to learn for somebody else - has also shifted attention away from the importance of relationships in educational processes and practices, and has thus made it far more difficult to explore what the particular responsibilities and tasks of educational professionals, such as teachers and adult educators, actually are.

As soon as it is acknowledged that the question of learning always raises further questions about its purposes, we can, on the one hand, begin to ask what desirable purposes of learning might be, while, on the other hand, we can begin to see the particular purposes that are being promoted in policies and practices for lifelong learning. With regard to the first issue, it has been known for a long time in the field of adult education that the learning of adults is not onedimensional, but can serve a range of different purposes. Aspin and Chapman (2001, pp. 39-40) helpfully make a distinction between three different agendas for lifelong learning: lifelong learning for economic progress and development; lifelong learning for personal development and fulfilment; and lifelong learning for social inclusiveness and democratic understanding and activity. Elsewhere (Biesta, 2010a), I have proposed a distinction between three domains of educational purpose: the domain of qualification, which has to do with the ways in which, through education, individuals become qualified to do certain things (this is the domain of the acquisition of knowledge, skills, values and dispositions); the domain of socialisation, which has to do with the ways in which, through education, individuals become part of existing social, political, professional, and other 'orders'; and the domain of subjectification, which, in opposition to socialisation, is not about how individuals become part of existing orders, but how they can be independent - or, as some would say, autonomous - subjects of action and responsibility. While qualification and socialisation can contribute to the empowerment of individuals in that they give them the power to operate within existing socio-political configurations and settings, subjectification has an orientation towards emancipation - that is, towards ways of doing and being that do not simply accept the given order, but have an orientation towards the change of the existing order so that different ways of doing and being become possible. I return to this below.

The problem with the language of learning, therefore, is that it tends to obscure crucial dimensions of educational processes and practices - that is, aspects of content, purpose and relationships. This not only means that the language of learning is a very unhelpful language in the field of education (and there is indeed evidence that this is impacting negatively on the ability of teachers to engage with the normative and political dimensions of their work - see, for example, Biesta, 2010a, p. 4) - which is why I have coined the ugly word 'learnification' to highlight this but also that it is obscuring the political 'work' that is done with and through the language of learning. To this issue I will now turn. 


\section{The Politics of Learning}

While there are many examples of the learnification of educational discourse in the domain of school, college and university education, the 'field' where this has happened most explicitly and most extremely is that of lifelong learning. As I have already indicated, the very fact that this field is now being called lifelong learning already highlights the impact of the language of learning on this domain. While the interest in the 'lifelong' dimension has been around for a long time - for example, in the work of Basil Yeaxlee in Britain and Eduard Lindeman in the USA (both in the 1920s) - the idea of 'lifelong' has for a long time been connected to the notion of education (the title of Yeaxlee's 1929 book was indeed Lifelong Education) and not to that of learning. Even in the 1970s, the rise of interest in the 'lifelong', so to speak, was always connected to education, such as in the landmark 1972 UNESCO report Learning to Be: the world of education today and tomorrow (Faure et al, 1972) or even in one of the early contributions by the Organisation for Economic Co-operation and Development to the discussion, the 1973 report Recurrent Education.

Two decades later, UNESCO was still pursuing the education line - for example, in the 1996 report Learning: the treasure within (Delors et al, 1996), but do note the title. This report not only argued for the need 'to rethink and broaden the notion of lifelong education' so that it not only focuses on adaptation 'to changes in the nature of work' but also constitutes 'a continuous process of forming whole human beings' (Delors, 1996, p. 19), but also argued for a shift in attention 'from social cohesion to democratic participation' (ch. 2) and 'from economic growth to human development' (ch. 3), paying explicit attention to the political, democratic and global dimensions of lifelong learning. Thus, Learning: the treasure within can, in a sense, be read as a response to a rapidly emerging alternative discourse on lifelong learning - one strongly characterised by an economic rationale and a focus on lifelong learning as the development of human capital.

The idea that lifelong learning is first and foremost about the development of human capital, so as to secure competitiveness and economic growth, played a central role in an influential document published by the Organisation for Economic Co-operation and Development in 1997 with the title Lifelong Learning for All. This put a strong emphasis on the economic rationale for lifelong learning, which was itself understood in the rather formal sense as learning 'throughout life' (Organisation for Economic Co-operation and Development, 1997, p. 15). It presented the idea of 'lifelong learning for all' as 'the guiding principle for policy strategies that will respond directly to the need to improve the capacity of individuals, families, workplaces and communities to continuously adapt and renew' (p. 13). Such adaptation and renewal are presented as necessary in the face of changes in the global economy and the world of work. Lifelong learning 'from early childhood education to active learning in retirement' is thus presented as 'an important factor in promoting employment and economic development', and, in addition to this, also in promoting 'democracy and social cohesion' (p. 13). Whereas, as mentioned, the Delors report made a case for shifting the attention from social cohesion to democratic participation and from economic growth to human development, Lifelong Learning for All went in the opposite direction where it concerns economic growth, and saw democracy and social cohesion as compatible 'agendas' rather than as agendas that are potentially in tension with each other (on this, see also Biesta, 2006b).

The shift from lifelong education to lifelong learning signifies a number of things. It is first of all a shift in orientation from lifelong education having to do with personal and democratic aims towards an economic if not economistic [2] rationale, in which lifelong learning becomes a matter of the abstract production of human capital, both at the level of individuals and their skills and competences and at the more macro level, where lifelong learning then appears as 'a key strategy to adjust human capital to new requirements' (ELLI Development Team, 2008, p. 8). It is, however, not only the orientation of lifelong learning that has changed; there are also important changes with regard to its form. One significant change is the ongoing individualisation of lifelong learning, something which Field (2000) shows empirically - his idea of a 'silent explosion' - but which can also be found ideologically, for example, in the emphasis on the need for individuals to adapt and adjust to the demands of the global economy in the reformulation of lifelong learning as the acquisition of a set of flexible skills and competencies, and also, of course, in the subtle but crucial semantic shift from 'lifelong education' - a relational concept - to 'lifelong learning' - an individualistic concept. 
While this is a matter of 'form', it is also a matter of politics. The most important shift at this level concerns the transformation of lifelong learning as a right that individuals can claim into a duty that all individuals need to live up to (as a more careful reading of the title of the Organisation for Economic Co-operation and Development's 1997 Lifelong Learning for All can reveal: not lifelong learning as available to all, but lifelong learning as demanded from all). Astrid Messerschmidt (2011, p. 18) connects this shift - which she characterises as the emergence of a kind of Bildungspflicht (a 'duty to Bildung') - to the Lisbon strategy and highlights, correctly in my view, that with the rise of the duty to Bildung, one of the key characteristics of adult education - namely, the voluntary nature of participation - has disappeared.

Elsewhere (Biesta, 2006b, pp. 175-176), I have argued that we can also see this shift as a reversal of rights and duties in that, under the lifelong education 'paradigm', individuals had a right to lifelong education and the state a duty to provide resources and opportunities, whereas, under the lifelong learning 'paradigm', individuals have ended up with the duty to learn throughout life whilst the state now seems to be in a position where it can claim the right to demand of all its citizens that they learn throughout their lives. One telling example of this is the rise of the notion of 'hard-to-reach learners' in lifelong learning policy in the United Kingdom and other Englishspeaking countries (see, for example, Brackertz, 2007), suggesting that somewhere in the dark corners of society there are still a few individuals who refuse to live up to their learning duty.

It is here that we can begin to see the politics of learning at work. There are a number of aspects to this. One key dimension of the politics of learning is the increasing tendency to turn political problems into learning problems, thus shifting the responsibility for addressing such problems from the state and the collective to the level of individuals. We can see this clearly in the rise of the economic rationale and the fact that individuals are made responsible for keeping up their employability in rapidly changing global markets, rather than the question being raised as to why such markets should rule over the economy and over social and political life more generally in the first place. The issue is entirely defined as a question of individual adaptation and adjustment - as a matter of learning - and not as one of structural issues and collective responsibilities.

The pressure is, however, not only coming from the outside, but also from the inside. This has to do with the very 'construction' of the lifelong learner identity as a process of Foucauldian 'governmentality', where individuals begin to identify with and then internalise the demand for lifelong learning. They thus do not simply become 'permanently learning subjects' (Field, 2000, p. 35) as a result of external pressures, but actually feel an internal 'need' to construct and conduct themselves in this way (see, for example, Forneck \& Wrana, 2005; Biesta, 2006b; Fejes, 2006). Rather than being a 'treasure within', learning thus turns into a 'pressure within', so that the politics of learning is being fed by our apparent will to learn (see Simons \& Masschelein, 2009).

The politics of learning is also at work in the shift from a democratic interest in lifelong education and lifelong learning towards an emphasis on social cohesion and integration. Part of the problem here - a simple but crucial one - is that a cohesive society is not necessarily or automatically also a democratic society. Also, notions of social integration and cohesion always raise the question as to who needs to be integrated into what or cohere with whom, and also who is allowed to set the agenda and define the terms of integration and cohesion (see also Biesta, 2010a, ch. 6). And again, lifelong learning is being mobilised to facilitate integration and cohesion through processes of adaptation and adjustment similar to those we have seen with regard to the 'demands' of the economy.

The final aspect of the politics of learning that I wish to highlight has to do with the naturalisation of learning - that is, with the tendency to see learning as an entirely natural phenomenon, on a par with breathing and digestion. To suggest that learning is simply part of our biological and increasingly also our neurological 'make-up', and therefore something we cannot help but do - something we cannot not do - leads to a slippery slope, where (1) learning first becomes equated with living, then (2) almost necessarily becomes a lifelong process, which (3) next moves to the claim that any normal human being can learn, and then (4) easily moves to the suggestion that therefore every normal human being should learn, so that (5), in the end, there must be something wrong with you if you do not want to learn and seek to refuse the learner identity.

To highlight these aspects of the politics of learning - that is, the political work which is being achieved through the notion and language and discourse of learning - is not to deny that there may 
be some good aspects to learning (although I am becoming less and less optimistic about this, precisely because of the problems outlined above), but to be aware that the language of learning, which fundamentally is individualistic, individualising and process-oriented rather than substantive, is not an innocent language, but actually a language which exerts a powerful influence on what we can be and how we can be - one that tends to domesticate rather than to emancipate. But if this is so, what are the opportunities for resistance and what might learning still have to do there? Let me now turn to these important questions.

\section{Denaturalising Learning Is Repoliticising Learning; Repoliticising Learning Requires Denaturalising Learning}

If part of the way in which the politics of learning is able to do its work stems from the suggestion that learning is a natural process and phenomenon, then the first step towards exposing the political work being done through learning is by denaturalising learning - that is, highlighting what we might call the 'artificial nature' of learning. One way to denaturalise the idea of learning is by acknowledging that 'learning' is an evaluative concept, not a descriptive one. If we start from the widely accepted definition of learning as any more or less durable change that is not the result of maturation, we can see that when we use the word 'learning' - for example, in such sentences as 'John has learned to ride a bicycle' or 'Mary has learned the first law of thermodynamics' - we are not so much describing change as making a judgment about change. The point is that when we observe John more carefully, we will probably be able to identify numerous things that have changed. The reason for identifying some of these changes as 'learning' and others as 'just changes' is because we value these changes either positively - for example, when we are proud that John has learned to ride his bike - or negatively - for example, when John has picked up some bad habits in the process - and because we have reason to believe that, at least to a certain extent, these changes are the result of interaction with an environment and not just the outcome of maturation.

This indicates that 'learning' is a term which expresses a judgement, which suggests that when we use the word 'learning' we are not so much describing a fact as evaluating an event. (We could say, therefore, that 'learning' is not a noun.) It is this judgement, then, that constitutes change as learning. To see 'learning' as an evaluative term can be an effective way to denaturalise the idea of learning because it allows us, each time the word 'learning' is being used, not only to ask what kind of judgement is being made - that is, what the reasons are for identifying particular change as learning - but also who is involved in making the judgement; who, in other words, claims the power to define particular change as learning (and other change 'just' as change).

The other way in which the idea of learning can be denaturalised is by simply refusing the very identity of a learner, thus showing that this identity is not inevitable, but can actually be refused (see also Simons \& Masschelein, 2009). Such a refusal can help to make visible that calling someone a learner is actually a very specific intervention, where the claim is made that the one who is being called a learner lacks something, is not yet complete or competent, and therefore needs to engage in further 'learning activity' (see also Biesta, 2010b). While, in some specific cases, it is entirely legitimate to make this assumption - for example, if one has an explicit desire to master a particular skill or gain particular knowledge or understanding - it is important to keep the learner identity confined to such cases and see it as a pragmatic, time-bound and situation-bound choice, and not as a natural state of affairs. Moreover, in some cases, it can actually be politically important to refuse the learner identity, particularly in those cases where, as mentioned above, the learner identity is being used to burden individuals with tasks, demands and duties that should be the responsibility of the collective. To refuse the learner identity and to claim that in some cases there is actually nothing to learn - for example, to claim that one can speak as a citizen without first having to learn what it means to speak 'properly' (see below and also Biesta, 2011) - is not to denounce the importance of learning, but to denaturalise and, hence, politicise learning so that choices, politics and power become visible. To refuse the learner identity thus, at the very same, exposes and opposes the politics of learning at work. 


\section{Emancipation without Learning?}

If the ideas presented so far make some sense, I would, in the final step of this article, like to connect them to the difficult but important issue of emancipation. After all, if it is the case that learning has to a large extent become an instrument of domestication if not - to use the beautiful word for which we have to thank the translator of Rancière - an instrument of 'stultification', then the important question for (us) educators is whether we can still envisage opportunities for emancipation and, more specifically, emancipation without learning. There are two authors who, in my view, have made important contributions to this challenge - one being Michel Foucault, the other being Jacques Rancière. I will confine myself here to a discussion of Foucault's ideas as an example of an understanding of emancipation without learning.[3] Let me, in this section, say something about the role learning plays in 'modern' understandings of emancipation in order to then, in the next section, see whether, with Foucault, we can envisage emancipation without learning.

The idea that emancipation requires learning is one that partly has come to us from the Enlightenment and Immanuel Kant's suggestion that we can escape or overcome our immaturity our determination by the other - if we have the courage to make use of our rational capacities. But, more explicitly, the connection between emancipation and learning can be found in the Marxist idea that in order to liberate ourselves from the oppressive workings of power, we need to expose how power operates. What the Marxist tradition adds to this basic idea - and this has, in turn, strongly influenced critical and emancipatory pedagogies - is the notion of ideology, where the claim is not only that all thought is socially determined, but also that ideology is thought which denies this determination. The 'predicament of ideology' lies in the suggestion that it is precisely because of the way in which power works upon our consciousness that we are unable to see how power works upon our consciousness (see Biesta, 2010c). This not only implies that in order to free ourselves from the workings of power, we need to expose how power works upon our consciousness, but it also means that in order for us to achieve emancipation, someone else, whose consciousness is not subjected to the workings of power, needs to provide us with an account of our objective condition (on this theme, see also Honig, 2003). According to this line of thought, therefore, emancipation is ultimately contingent upon the truth about our objective condition, a truth that can only be generated by someone who is positioned outside of the influence of ideology.

The educational 'translation' of this 'logic' of emancipation basically takes two forms - one which can be characterised as monological and one which can be characterised as dialogical. The monological approach is the most direct translation of the ideas outlined above. It relies on the assumption that emancipation requires an intervention from the outside - an intervention, moreover, by someone who is not subjected to the power that needs to be overcome. Thus, emancipation appears as something that is done to somebody and hence relies on a fundamental inequality between the emancipator and the one to be emancipated. Equality, on this account, becomes the outcome of emancipation; it becomes something that lies in the future. Moreover, it is this outcome which is used to legitimise the interventions of the emancipator. This is a 'logic' of emancipatory education - a logic that we might also call 'colonial' (see, for example, Andreotti, 2011) - in which the teacher knows and students do not know yet; where it is the task of the teacher to explain the world to the students and where it is the task of the students to ultimately become as knowledgeable as the teacher. In this set-up, there is a clear learning task for the student - a task which is basically reproductive in that it is aimed at the acquisition of the insights of the teacheremancipator.

It is one of the main achievements of Paulo Freire to have provided a dialogical alternative in which emancipation is no longer seen as a process of truth-telling by the teacher-emancipator Freire's notion of 'banking education' - but where it becomes a process of the collective discovery of oppressive structures, processes and practices, a process in which teacher and students are positioned as 'co-subjects' (Freire, 1972, p. 135). Freire characterises oppression as the situation in which individuals are disconnected from the world and exist as objects of the oppressor's actions, rather than as subjects of their own actions. Oppression is thus understood as a process of 'dehumanisation' that occurs when people's natural ways of 'being-in-praxis' are disrupted or suppressed (Freire, 1972, p. 135). Emancipation, on this account, is aimed at restoring the 
connection between human beings and the world; or, in Freire's vocabulary, restoring praxis. The role of the teacher in this process is to reinstigate dialogical and reflective practices which, in turn, reinitiate praxis and link people back to the world (Freire, 1972, p. 30). For Freire, emancipation therefore also involves learning - and more, perhaps, than in the banking model of education, this is an ongoing and, in a sense, lifelong process. The learning is, however, not reproductive, but constructive or generative, albeit that it still has an orientation towards truth. Unlike in the monological model, this is not the truth given by the teacher to students about their objective condition on the assumption that students are unable to acquire such insights themselves.

\section{For Example: Foucault and the practice of transgression}

Although I have shown that truth occupies a different position in the monological approach and in the dialogical approach, both approaches ultimately rely on the possibility of truth and, more specifically, truth uncontaminated by power. In the monological approach, this truth is learned from (and thus given by) the teacher; in the dialogical approach, this truth is discovered through a collective learning process. That the monological approach relies on the idea of truth uncontaminated by power has to do with the fact that emancipation is seen as a process of overcoming ideological distortions. Here, emancipation operates as a process of demystification. In the dialogical approach, emancipation is the process that restores true human existence - or, in Freirean language, true human 'praxis'. In both cases, truth is needed to overcome alienation either the alienation produced by false consciousness or the alienation brought about by oppression. For truth to be able to do this 'work', it must be assumed that there is a fundamental distinction between truth and power - and one could indeed argue that this distinction is foundational for the modern project of Enlightenment (see, for example, Habermas, 1990), evidence of which we can find in the idea of 'speaking truth to power'.

One author who has challenged this very assumption is Michel Foucault. He has argued that power and knowledge never occur separately but always come together - something which is expressed in the idea of 'power/knowledge'. This is why he has suggested that we should abandon 'the whole tradition that allows us to imagine that knowledge can only exist where the power relations are suspended' (Foucault, 1975, p. 27) - a tradition that forms the basis for both the monological and dialogical approaches to emancipation. Yet, to argue that we have to abandon this particular tradition is not to suggest that change is no longer possible. Rather, it is to highlight that we are always operating within power/knowledge 'constellations' - that is, of power/knowledge versus power/knowledge, and not of knowledge versus power or power versus knowledge. There is, therefore, potential for action, change and critique, but we have to understand this in terms that are fundamentally different from the idea that emancipation is an escape from power.

Foucault (1984, p. 45) agrees with Enlightenment thinkers such as Kant that criticism 'consists of analyzing and reflecting upon limits'. But,

if the Kantian question was that of knowing what limits knowledge had to renounce

transgressing ... the critical question today has to be turned back into a positive one: in what is given to us as universal, necessary, obligatory, what place is occupied by whatever is singular, contingent, and the product of arbitrary constraints? (Foucault, 1984, p. 45)

In some of his work, Foucault has referred to this approach as 'eventalization'. 'Eventalization' 'means making visible a singularity at places where there is a temptation to invoke a historical constant, an immediate anthropological trait, or an obviousness which imposes itself uniformly on all' (Foucault, 1991, p. 76).[4] 'Eventalization' works 'by constructing around the singular event ... a "polygon" or rather a "polyhedron" of intelligibility, the number of whose faces is not given in advance and can never properly be taken as finite' (Foucault, 1991, p. 77). 'Eventalization' thus means to complicate and to pluralise our understanding of events, their elements, their relations and their domains of reference.

'Eventalization' therefore does not result in a deeper understanding, an understanding of underlying structures or causes, and, in this respect, it does precisely not generate the kind of knowledge that will set us free from the workings of those structures or causes. But Foucault has been adamant that this does not mean that such analysis is without effect. What 'eventalization' does not generate, so he has argued, is advice, guidelines or instructions as to what is to be done. 
But what it can bring about is a situation in which people "no longer know what they do", so that the acts, gestures, discourses which up until then had seemed to go without saying become problematic, difficult, dangerous' - and this effect, so he argues, is entirely intentional (Foucault, 1991, p. 84). 'Eventalization' therefore does not result in a deeper or truer understanding of how power works - it only tries to unsettle what is taken for granted - nor does it aim to produce recipes for action. This kind of analysis is therefore not meant to solve problems; it is not a kind of knowledge meant for 'social workers' or 'reformers', but rather for subjects who act. As Foucault explains:

Critique doesn't have to be the premise of a deduction which concludes: this then is what needs to be done. It should be an instrument for those who fight, those who resist and refuse what is. Its use should be in processes of conflict and confrontation, essays in refusal. It doesn't have to lay down the law for the law. It isn't a stage of programming. It is a challenge directed to what is. (Foucault, 1991, p. 84)

Rather than to think of emancipation as an escape from power, Foucault envisages emancipation as 'practical critique that takes the form of a possible transgression' (Foucault, 1984, p. 45; my emphasis). The critical practice of transgression is not meant to overcome limits (not in the least because limits are not only constraining, but always also enabling - see Simmons, 1996, p. 69). Transgression, rather, is the practical and experimental 'illumination of limits' (Foucault, 1977, pp. 33-38; Boyne, 1990), such as in the attempt to see how far we can go in denying the very existence of learning, or the very suggestion that learning has anything to do with us or that we have anything to do with learning.

Foucault's rejection of the founding distinction of the modern Enlightenment - that is, the distinction between truth and power - does therefore not imply the end of the possibility of emancipation and the end of the possibility of critique, but changes emancipation from an endeavour based on truth - either the truth to be given by the teacher-emancipator or the truth discovered through collective critical learning - into the practical task of transgression. Transgression means doing things differently in order to show - or to prove, as Foucault would say - that things can be different and that the way things are is not the way things necessarily should be, that is, that we can also not be a lifelong learner. Thus, the emancipatory potential of transgression lies in the possibility 'of no longer being, doing, or thinking what we are, do, or think', and, in precisely this sense, Foucault (1984, p. 46) suggests, 'it is seeking to give a new impetus ... to the undefined work of freedom'.

With Foucault, we can thus begin to see the contours of a different understanding of, and approach to, emancipation, one where emancipation is no longer an escape from power through demystification, but becomes a practice of transgression - the practical confrontation of different power/knowledge constellations - in order to show that things do not have to be the way they currently are. There is critical work to be done in relation to this, but this is not a process of demystification, of speaking truth to power, but one of 'eventalization' - that is, of the pluralisation of truth. This also means - and this is quite important for the discussion - that the role of learning in emancipation becomes a radically different one. In one sense, we could say that, if we follow Foucault, there is no longer anything to learn, at least not if we see learning as the condition for emancipation. There is, to be more precise, nothing to learn about our objective condition because, if we follow Foucault, we have to give up the idea that we can make a distinction between our objective condition and our distorted understandings of this condition. Similarly, there is nothing to learn about our true human existence because, if we follow Foucault, we have to give up the idea that there is one single true human existence. There are many, which is not to suggest that they are all of equal value or worth, or that human existence is without limits.

While there is, therefore, no longer the suggestion that a particular kind of learning - a learning that discloses the truth - will result in emancipation, this does not mean that there is nothing to pick up from transgression and pluralisation, as long as we bear in mind that these processes themselves are not driven by learning. It is the transgression and pluralisation that come first, and what we pick up from our engagement in such emancipatory experiments comes second (and what we do with that is still another matter). In this regard, Foucault's approach does suggest a different connection between learning and emancipation - and one could also say that, given the fact that the work of freedom for Foucault is undefined, the process will never come to an end. In 
this regard, emancipation is a lifelong challenge (not unlike what Freire had in mind, albeit on different terms); freedom is not a point or a state we can ever reach.

\section{Conclusions}

In this article, I have tried to raise some critical questions about the notion of 'learning', the language of 'learning' and the discourse of 'learning'. My intention has been to unsettle a little the positive if not warm feelings we, as educators, educationalists and people working for change for the better, may have for learning, showing the political 'work' that is being done through this notion, particularly the political work that keeps us in our place and domesticates and stultifies us, rather than helping us to act differently and be different. I have done this, first of all, by showing some of the problems with the language of learning in educational settings, highlighting the fact that the language of learning tends to obscure those dimensions that make education educational, so to speak. Here, I have particularly highlighted the way in which questions about content, purpose and relation easily disappear from view when we start to talk about education in terms of, and through, the individualistic and individualising process-language of learning. I have, through a discussion of transformations in the field of lifelong learning, tried to highlight how, through the very idea of 'learning', a lot of political work is done, and that the very construction of lifelong learning as a 'field' is already an example of the politics of learning at work. Against this background, I have suggested that there is a need for interrupting the politics of learning.

A starting point for such interrupting is to resist the suggestion that learning is a natural process and thus something that simply 'occurs' - as if beyond our control. In addition, I have highlighted the importance of refusing the very identity of a learner and, more specifically, of a lifelong learner - a refusal that at the same time can expose and oppose the workings of the politics of learning. In the final step, I have connected this to the discussion on emancipation in order to show that to give up the notion of learning does not mean to give up on the idea of emancipation. I have used Foucault as an example of what emancipation without learning - which, for Foucault, becomes emancipation as transgression - might look like, also showing how my critique of the politics of learning can itself be understood as an attempt at transgression. This is not - or not yet a wholesale denouncement of the idea of learning, as I still want to be open to the possibility that learning can also work for the good (although, as mentioned, I am becoming increasingly pessimistic about this possibility). The crucial issue here is whether it is up to us to decide whether we learn or not, whether to adopt the learner identity or not, or whether we can only subject ourselves to ongoing demands for learning, and ongoing demands to fashion ourselves as lifelong learners - that is, whether we can only succumb to the duty to learn. This is why I believe that we not only need to continue to interrupt the politics of learning, but that, perhaps as part of this, we also need to change the discourse of education from a discourse that relies on the language of learning to one that can be educational beyond learning (Biesta, 2006a).

\section{Acknowledgements}

This article is based on an invited keynote presentation given at the 2012 Discourse, Power and Resistance conference in Plymouth, United Kingdom. I would like to thank the organisers of the conference for the invitation to present my ideas, and am grateful to many of the participants for their encouraging feedback.

\section{Notes}

[1] See the Wikipedia page for Watercliffe Meadow at http:/ / en.wikipedia.org/wiki/Watercliffe_Meadow

[2] I use 'economistic' here as referring to the idea of the economy as an aim and value in itself, which is similar to the difference between 'scientific' and 'scientistic'.

[3] For Rancière and for more details of the idea of emancipation without learning, I refer the reader to Bingham \& Biesta (2010) and Biesta (2012b). 
[4] What I have tried to do with the notion of 'learning' in the earlier parts of this article can precisely be understood in this way.

\section{References}

Andreotti, V. (2011) Actionable Postcolonial Theory in Education. New York: Palgrave Macmillan. http: / / dx.doi.org/10.1057/9780230337794

Aspin, D.N. \& Chapman, J.D. (2001) Lifelong Learning: concepts theories and values, in Proceedings of the 31st Annual Conference of SCUTREA. London: Standing Conference on University Teaching and Research in the Education of Adults, University of East London.

Biesta, G.J.J. (2006a) Beyond Learning: democratic education for a human future. Boulder, CO: Paradigm.

Biesta, G.J.J. (2006b) What's the Point of Lifelong Learning if Lifelong Learning Has No Point? On the Democratic Deficit of Policies for Lifelong Learning, European Educational Research Journal, 5(3/4), 169-180. http:/ / dx.doi.org/10.2304/ eerj.2006.5.3.169

Biesta, G.J.J. (2010a) Good Education in an Age of Measurement: ethics, politics, democracy. Boulder, CO: Paradigm.

Biesta, G.J.J. (2010b) Learner, Student, Speaker: why it matters how we call those we teach, Educational Philosophy and Theory, 42(4), 540-552. http:/ / dx.doi.org/10.1111/j.1469-5812.2010.00684.x

Biesta, G.J.J. (2010c) A New 'Logic' of Emancipation: the methodology of Jacques Rancière, Educational Theory, 60(1), 39-59. http:/ / dx.doi.org/10.1111/j.1741-5446.2009.00345.x

Biesta, G.J.J. (2011) The Ignorant Citizen: Mouffe, Rancière, and the subject of democratic education, Studies in Philosophy and Education, 30(2), 141-153. http: / / dx.doi.org/10.1007/s11217-011-9220-4

Biesta, G.J.J. (2012a) Everything You Always Wanted to Know about Lifelong Learning (but Were Afraid to Ask): is critical research on lifelong learning possible? And is it desirable? Paper presented at 23rd Congress of the Deutsche Gesellschaft für Erziehungswissenschaft, Osnabrück, 12-14 March.

Biesta, G.J.J. (2012b) Have Lifelong Learning and Emancipation Still Something to Say to Each Other? Studies in the Education of Adults, 44(1), 5-20.

Bingham, C. \& Biesta, G.J.J., with Rancière, J. (2010) Jacques Rancière: education, truth, emancipation. London: Continuum.

Boyne, R. (1990) Foucault and Derrida: the other side of reason. London: Routledge.

Brackertz, N. (2007) Who Is Hard to Reach and Why? Institute of Social Research Working Paper. Melbourne: Swinburne University of Technology.

Delors, J. (1996) Learning: the treasure within. Paris: UNESCO.

Department for Education and Employment (1998) The Learning Age: a renaissance for a new Britain. London: The Stationery Office.

Derrida, J. (1994) Spectres of Marx. New York: Routledge.

ELLI Development Team (2008) European Lifelong Learning Indicators: developing a conceptual framework. Gütersloh: Bertelsmann Stiftung.

Faure, E., Herrera, F., Kaddoura, A.-R., Lopes, H., Petrovsky, A.V., Rahnema, M. \& Champion Ward, F. (1972) Learning to Be: the world of education today and tomorrow. Paris: UNESCO.

Fejes, A. (2006) Constructing the Adult Learner: a governmentality analysis. Linköping: Linköping University.

Field, J. (2000) Lifelong Learning and the New Educational Order. Stoke-on-Trent: Trentham Books.

Forneck, H.J. \& Wrana, D. (2005) Transformationen des Feldes der Weiterbildung, in H.J. Forneck \& D. Wrana (Eds) Ein parzelliertes Field: eine Einfuihrung in die Erwachsenenbildung. Bielefeld: Bertelsmann.

Foucault, M. (1975) Discipline and Punish: the birth of the prison. New York: Vintage Books.

Foucault, M. (1977) A Preface to Transgression, in D.F. Bouchard (Ed.) Language, Counter-Memory, Practice: selected essays and an interview by Michel Foucault. Ithaca, NY: Cornell University Press.

Foucault, M. (1984) What Is Enlightenment? In P. Rabinow (Ed.) The Foucault Reader. New York: Pantheon Books.

Foucault, M. (1991) Questions of Method, in G. Burchell, C. Gordon \& P. Miller (Eds) The Foucault Effect: studies in governmentality. Chicago: University of Chicago Press.

Freire, P. (1972) Pedagogy of the Oppressed. London: Penguin.

Habermas, J. (1990) The Philosophical Discourse of Modernity. Cambridge, MA: MIT Press.

Honig, B. (2003) Democracy and the Foreigner. Princeton, NJ: Princeton University Press. 
Meirieu, P. (2007) Pédagogie: le devoir de résister. Issy-les-Moulineaux: ESF Editeur.

Messerschmidt, A. (2011) Weiter bilden? Anmerkungen zum lebenslangen Lernen aus erwachsenenbildnerischer und bildunstheoretischer Perspektive, in Kommision Sozialpädagogik (Ed.) Bildung des effective Citizen: Sozialpädagogik auf dem Weg zu einem neuen Sozialentwurf. Weinheim: Juventa.

Organisation for Economic Co-operation and Development (OECD) (1973) Recurrent Education: a strategy for lifelong learning. Paris: OECD.

Organisation for Economic Co-operation and Development (OECD) (1997) Lifelong Learning for All. Paris: OECD.

Simmons, J. (1996) Foucault and the Political. London: Routledge.

Simons, M. \& Masschelein, J. (2009) Our Will to Learn and the Assemblage of a Learning Apparatus, in A. Fejes \& K. Nicoll (Eds) Foucault and Lifelong Learning. London: Routledge.

Yang, J. \& Valdés-Cotera, R. (Eds) (2001) Conceptual Evolution and Policy Developments in Lifelong Learning. Hamburg: UNESCO Institute for Lifelong Learning.

Yeaxlee, B.A. (1929) Lifelong Education. London: Cassell.

GERT BIESTA (www.gertbiesta.com) is Professor of Educational Theory and Policy in the Faculty of Language and Literature, Humanities, Arts and Education at the University of Luxembourg. He previously worked at several universities in the Netherlands and at the University of Exeter and University of Stirling in the United Kingdom. He has published on the theory and philosophy of education, education policy, and the theory and philosophy of educational and social research, and is particularly interested in questions of citizenship, democracy and democratisation. He is editorin-chief of the journal Studies in Philosophy and Education and founding co-editor of Other Education: The Journal of Educational Alternatives. Recent books include Good Education in an Age of Measurement (Paradigm, 2010) and Learning Democracy in School and Society (Sense, 2011). His latest book, The Beautiful Risk of Education, will be published by Paradigm in 2013. Correspondence: gert.biesta@uni.lu 